\title{
Performance of imputation-based models in predicting breeding population trend of a near-threatened bird in changing water regime: $A$ 36-year long-term case study of Painted Stork, Mycteria leucocephala
}

\author{
Rajneesh Dwevedi* \\ Amity Institute of Forestry and Wildlife, Amity University, Noida (Uttar Pradesh), India \\ Vishal Deo \\ Department of Statistics, Ramjas College, University of Delhi, Delhi, India \\ Janmejay Sethy \\ Amity Institute of Forestry and Wildlife, Amity University, Noida (Uttar Pradesh), India \\ Renuka Gupta \\ Department of Biology, Lady Irwin College, University of Delhi, Delhi, India \\ Mahendiran Mylswamy \\ Wetland Ecology Division, Salim Ali Centre for Ornithology and Natural History, Coimbatore \\ (Tamil Nadu), India \\ *Correspondence author. Email: dwevedi.rajneesh@gmail.com
}

\author{
Article Info \\ https://doi.org/10.31018/ \\ jans.v13i3.2876 \\ Received: July 23, 2021 \\ Revised: September 7, 2021 \\ Accepted: September 10, 2021
}

\section{How to Cite}

Dwevedi, R. et al. (2021). Performance of imputation-based models in predicting breeding population trend of a near-threatened bird in changing water regime: A 36-year long-term case study of Painted Stork, Mycteria leucocephala. Journal of Applied and Natural Science, 13(3), 1072 - 1082. https://doi.org/10.31018/jans.v13i3.2876

\begin{abstract}
The breeding population of birds are dynamic and are affected by multiple factors including climate and local environmental conditions. However, often to understand such relations requires long-term data modelling. Such long-term population data is either lacking or has data gaps. This study demonstrates the use of Multiple Imputation Chained Equation (MICE) to overcome the problem of missing data population census. This is also the first comprehensive study, modelling the 36-year (1980-2015) long-term breeding population data of a near-threatened bird, Painted Stork, from Keoladeo National Park, India. It tests the effect of local water availability, i.e., water released to the park, and regional rainfall, i.e, climatic condition, on the breeding population using Generalised Additive Model (GAM). Both imputation and observed data series-based GAM models identified the local water availability as the most important factor influencing the breeding population of Painted Stork. More than $80 \%$ population decline was observed, despite a slight increase in the rainfall at regional scale, suggesting local hydrological conditions are limiting to the breeding population and not the climate. According to the visual assessment of partial plot of GAM, minimum 200300 million cubic feet of water is needed each nesting season to ensure sustenance of breeding population. Post-1989, the breeding population was unable to match the long-term mean ( 726) except in 1992, 1995, and 1996. The maximum decline was observed between 2000-2009, a decade of frequent droughts. The breeding population was stable until the end of this study, but it was far below the long term mean.
\end{abstract}

Keywords: Generalised additive model, Multiple imputation Chained equation, Painted stork, Population trend

\section{INTRODUCTION}

Long-term studies play an important role in understanding many ecological questions ranging from behavioural to community ecology (Franklin, 1989; Frederick and Meyer, 2008; Janzen and Ellert, 2017; Kampichler et al., 2014; Reinke et al., 2019). Long-term studies enable us to understand cyclic patterns in a given population otherwise impossible in short-term studies (Franklin, 1989; Karell et al., 2009). Modelling long-term ecosystem dynamics is useful in managing and conserving ecosystems (Ma et al., 2004; Shipley et al., 2020; Taft et al., 2002; Weimerskirch 2018; Wen et al., 2011). Several researchers have modeled various aspects of ecosystems concerning bird ecology using long-term studies. These aspects include wetland productivity, food availability, land use, habitat preferences, climate, hydrological trends, population dynamics and conservation (Bowler et al., 2019; Briggs et al., 1997; Dean \& Milton, 2001; Fewster et al., 
2000; Frederick and Ogden, 2001; Karell et al., 2009; Knape et al., 2016; Maxwell et al., 2019; Messerendino et al., 2011; Reid et al., 2013; Reinke et al., 2019; Weimerskirch, 2018; Wen et al., 2011). However, the availability of suitable data requires well designed systematic monitoring, skill-based unbiased and continuous observations (Lindenmayer and Likens 2009; Russell et al., 2002).

One of the challenges in a long-term study is missing count creating uncertainty in ecological models (Atkinson et al., 2006; Franklin, 1989; Lindenmayer \& Likens, 2009; Russell et al., 2002). Many studies have suggested different statistical models, such as kNN; MICE, to overcome missing data problems (Nakagawa and Freckleton, 2008; Penone et al., 2014). Some of these models were also developed on bird populations (Penone et al., 2014). These have been used on terrestrial as well as water birds, including waterfowls and waders. Most of the long-term studies have been conducted on North American and European birds, as a systematic census of birds is available from these regions (Baker et al., 2019; Freeman et al., 2007, Kamp et al., 2021; Sauer et al., 2017; Shipley et al., 2020; Weimerskirch 2018).

Painted Stork breeding population is well monitored at KNP and hence can be used to model the long-term temporal trend and effect of water availability. It is a large wader and is listed under the near-threatened category of IUCN (Birdlife International, 2019). Being a top predator in a wetland, it can also be used as a good indicator of ecosystem health (Frederick et al., 2009; Sergio et al., 2008). However, despite the availability of information and statistical tools, no long-term based ecological models are available to predict the long-term impacts on the breeding population. This study is the first effort to compile long-term breeding data of a large colonial bird from a wetland ecosystem in India. Authors use 36-year (1980 -2015) long-term data to develop a statistical model on the breeding population of Painted Stork in Keoladeo National Park (KNP). In addition, regional rainfall was taken as a surrogate of climate in the study. Such a longterm-based statistical model will be useful in identifying the effect of climatic and hydrological patterns.

The objective of this study was to first identify the trend in the breeding population of Painted Stork and water availability in KNP, second to identify, compare and assess the performance of a suitable imputation based statistical model to predict the breeding population; and the third to model the effect of climate water availability on the breeding population of Painted Stork.

\section{MATERIALS AND METHODS}

\section{Study area}

Keoladeo National Park (KNP) is a $29 \mathrm{~km}^{2}$ area situated on the edge of the Gangetic basin at the old conflu- ence of Rivers Gambhir and Banganga in district Bharatpur, Rajasthan, India. (Fig. 1). KNP supports a large diversity of fauna and flora, and has a unique mosaic of habitats that includes wetlands, woodlands, scrub forests and grasslands (Vijayan, 1987). With the beginning of monsoon, large number of colonial birds starts to aggregate in KNP. Congregation and nesting start from June-July and continue to stay till February-March in the park. These birds either forage locally or fly out to different wetlands outside the park. Several wetlands in the vicinity have been identified where colonial birds have been found to be foraging (Vijayan, 1991). Ecology of KNP is dependent on monsoonal rainfall and water received through the Ajan dam located south of the park(Ali 1953; Ali and Vijayan, 1983).

\section{Data collection and analysis \\ Breeding population (Nest count)}

Breeding population data was extracted from secondary data, i.e., published reports and park management. The data source included a decade-long (1980-1990) study of Keoladeo National Park by BNHS (Ali and Vijayan, 1983; Sankhala 1990; Vijayan, 1987; Vijayan, 1991). After 1990, KNP management started a heronry monitoring program (1991-till date). Above monitoring and research data includes nest count of 15 heronry species, including Painted Stork. Data from the above sources were compiled, and a series of nest counts were prepared from 1980 to 2015 . There were few missing data $(25 \%)$ in the nest count either because of nesting/breeding failure.

\section{Water availability}

Water released from Ajan Dam and local rainfall (rainfall observed at Ajan rainfall station) were correlated. Hence the volume of water released in the nesting year from various water dams/canals was designated as water availability in the nesting year (WR). In few years $(2002,2006,2007$, and 2009), it was observed that no water was released from Ajan Dam to the park, hence some zero values are present in the data. To remove zero value, data was transformed by adding a one-unit value to each data point $(N Y W R=W R+1)$. Water availability was represented at two temporal scales: the nesting year water availability and water availability five years before the nesting year. Two variables were derived from this information, one nesting year water availability (NYWR) and mean water availability in the five years before nesting (MPYWR5). NYWR represented immediate habitat quality and MPYWR5 long-term habitat quality. WR data was obtained from the park management and rainfall data was downloaded from the Water Resource Department of Rajasthan Government website (Water Resource Department Rajasthan, 2019). 


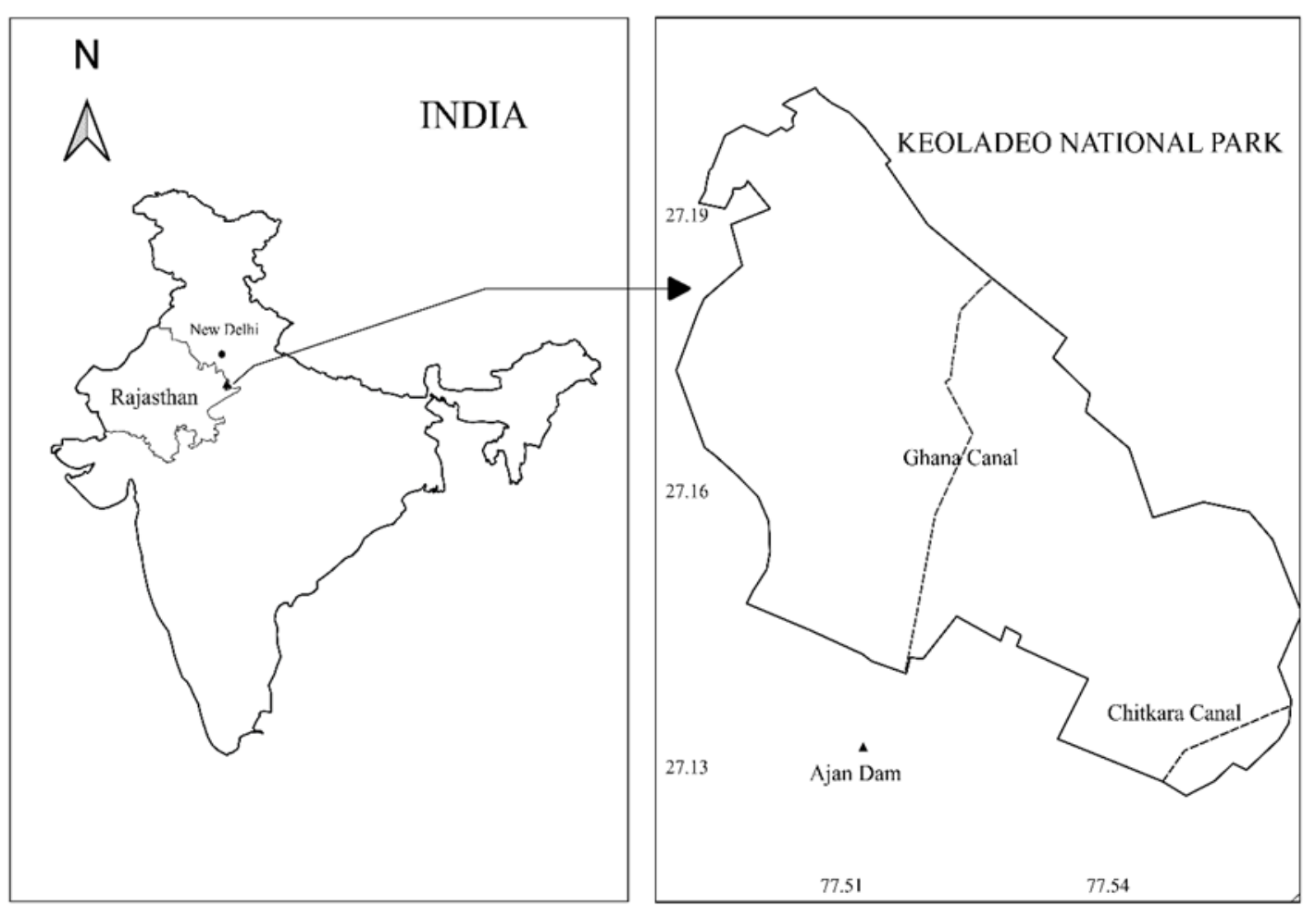

Fig. 1. Map showing location of Keoladeo National Park in India

Keoladeo is located in the Bharatpur district of eastern Rajasthan and hence rainfall received in the Eastern Rajasthan region was also used to represent regional water availability (RFR). This parameter was taken as a surrogate of habitat quality at a large spatial scale. Rainfall data was downloaded from the website of the Water Resource Department, Government of Rajasthan, India (Water Resource Department Rajasthan, 2019).

\section{Statistical analysis \\ Trend identification of water availability and breed- ing population}

All parameters, nesting year water availability (NYWR), mean water availability five years before nesting (MPYWR5), regional rainfall (RFR) and nest count were tested for long-term trend using ModifiedKendall's (MK) test (Hamed and Rao 1998). MK test is not affected by autocorrelation in the data hence used in the trend detection. Trend detection requires continuous data which was a limitation in this study. This limitation was overcome by generating imputed series of nest counts. Multiple Imputation Chained Equation (MICE) was used to generate five imputed series (imp1, imp2, imp3, imp4, and imp5) of nest count (Groothuis-Oudshoorn and Van Buuren, 2011, Penone et al., 2014). Hence, two nest count series were tested for further analysis, 1) Imputed nest count series, with no missing values and 2) Observed nest counts, with missing values removed from the data.
Data assessment and pre-modelling considerations A generalized additive model (GAM) was used to model the breeding population using GAMLSS package available in programme $\mathrm{R}$ (Stasinopoulos and Rigby, 2007). Nest count data had several missing values with non-normal distribution (Shapiro-Wilk Test, $W=$ $0.91198, p$ value $=0.03374)$. Therefore other GAM distribution functions were tested for best fit. GAM can be used with non-normal distribution functions for population (count) data, giving more flexibility in data fitting (Lindén and Mäntyniemi, 2011; Stasinopoulos and Rigby, 2007; Wen et al., 2011). It is suitable to use negative binomial distribution for bird count data (Fewster et al., 2000; Knape, 2016; Miserendino et al., 2011; Ramo et al., 2013; Wen et al., 2011). Therefore nest count data was tested only for negative binomial distributions (BNB, NBI, NBII, ZIBNB, NBF, ZINBF, ZINBI, and ZANBI) available in GAMLSS package (see Stasinopoulos and Rigby, 2007 for more details). The best distribution function was selected using the Generalized Akaike Information Criterion (GAIC, smaller values show a better fit) (Akaike, 1974).

\section{Model consideration and assessment}

It was hypothesized that the breeding population of Painted Stork (Nest Count) is a function of the present (NYWR), long-term (MPYWR5) and regional (RFR) water availability. So, the following model was tested for its validity and performance,

Nest Count $\sim$ Year + NYWR + MPYWR5+RFR ....Eq.1 
Year (time) was included to test the effect of any other temporal factors on the breeding population. GAM models were run in the program $R$, which included all possible predictor variables as mentioned in the abovehypothesized model. Final predictor variables were shorted using the stepGAIC() function in the GAMLSS package. This method excludes a variable with the highest $p$-value based on Chi-square statistics. Further other alternate models are assessed and compared using GAIC values. Model suitability was tested using Worm plots. Worm plot, a de-trended Quantile-quantile (Q-Q) plot, allows visual assessment of model fit to the data. Pseudo R Squared value (Generalized R Squared) was used to find the selected model's goodness of fit. Pseudo $R$ square is a method to calculate deviance justified by the model. The above model was applied to both imputed nest count and observed nest count series to identify the effect of missing values on model performance.

\section{RESULTS}

Trend identification of water availability and breeding population

Water released in the nesting year (NYWR) showed large variation (Mean $=320.7 \mathrm{mcf}, \mathrm{SD}=203.03$ ) with insignificant negative trend (Corrected $Z c=-1.02$, Tau= 0.12 , Sen's slope $=-3.0$, New p-value $=0.31)$. Water availability in the five years prior to nesting (MPYWR5) showed significant negative trend over 36-years (Corrected Zc=-2.7, Tau= -0.34, Sen's slope= -4.97 , New p-value $=0.007)$. A small increase was detected in regional rainfall (RFR) (Corrected $\mathrm{Zc}=1.33$, Tau $=0.21$, Sen's slope $=3.28$, New p-value $=0.08$ ). Breeding population showed a significant negative trend (Corrected $Z c=-3.16$, Tau= -0.49 , Sen's slope $=-56.18$, New $p$ value $=0.002)$ over 36-years (1980 - 2015). Above results were obtained using observed nest count series, similar negative trends were observed with the imputed series of nest count in the trend detection (Table 1).

\section{Pre-modelling distribution fit assessment and GAM model performance}

All tested negative binomial distributions performed well for nest count distribution fit (see Fig. 2) except for ZIBNB, for which algorithms did not converge. Negative binomial I and II distribution function were found to be the most appropriate to model the data sets (see Table 2). Performance of NBI and NB II were assessed in the final GAM model.

GAIC values obtained from stepwise GAMLSS are summarized in Table 3. NB II model performed better than the NB I GAM model (see worm plot in Fig. 3). Visualization of worm plot clearly shows the few values are outside the confidence range of the tested model for NBI. NB II performed better, hence results obtained from it were used to interpret the model outcome. NBIl based GAM model adequately explained the variance of the nest count (Pseudo R Square $=0.63$ ). Time and water released in the nesting year (NYWR) were selected as the predictor of the nest count in the final model. Water availability prior to nesting year (MPYWR5) and regional rainfall (RFR) were excluded from the final model. Imputed series -based model also performed similarly (Table 4 and Fig. 4). Imputation-based models could explain $43 \%$ to $63 \%$ variability in the nest count (Table 3 ).

\section{Effect of predictor variables on the breeding population of Painted Stork}

The breeding population has significantly declined in the past 36 years (Estimates $=-0.04$, Fig. $5 \mathrm{~A}$ ). Data fitted well except for one year (1986) when an extremely low number of nests were recorded. Maximum reduction in the nest count was observed between 2000$2009(45 \%)$ from the base decade's mean population (Table 5). Periodic observation of mean nest count shows $>80 \%$ decline in the breeding population compared to the base decade, i.e., 1980-1989 ( Table 5). Local water availability (NYWR) has a positive effect on nest count (Estimates $=0.00213$ ). Nest count has a loglinear relationship with local water availability ( Fig. 5B). Nest Count is higher when local water availability (NYWR) is between 400-600 million cubic feet (Fig. $5 \mathrm{~B})$. It is observed that in few years, despite no rainfall deficit, KNP received less than the long-term mean of water released (NYWRMean $=320$ million cubic feet) (Fig. 6). The breeding population was negatively affected by time (year) (Table 3), confirming a negative tem-

Table 1. Summary of Mann-Kendall's trend test with imputed series of nest count

\begin{tabular}{llllll}
\hline $\begin{array}{l}\text { Variables/ } \\
\text { Parameters }\end{array}$ & Corrected Zc & Tau & Sen's slope & New Variance & New $p$ - value \\
\hline Imp 1 & $-4.91 \mathrm{E}+00$ & $-5.65 \mathrm{E}-01$ & $-2.91 \mathrm{E}+01$ & $5.82 \mathrm{E}+03$ & $8.92 \mathrm{E}-07$ \\
Imp 2 & $-4.01 \mathrm{E}+00$ & $-4.61 \mathrm{E}-01$ & $-2.61 \mathrm{E}+01$ & $5.82 \mathrm{E}+03$ & $6.02 \mathrm{E}-05$ \\
$\operatorname{Imp} 3$ & $-4.65 \mathrm{E}+00$ & $-4.83 \mathrm{E}-01$ & $-2.93 \mathrm{E}+01$ & $4.77 \mathrm{E}+03$ & $3.36 \mathrm{E}-06$ \\
$\operatorname{Imp~} 4$ & $-4.85 \mathrm{E}+00$ & $-5.57 \mathrm{E}-01$ & $-3.21 \mathrm{E}+01$ & $5.83 \mathrm{E}+03$ & $1.26 \mathrm{E}-06$ \\
$\operatorname{Imp~5}$ & $-3.86 \mathrm{E}+00$ & $-4.44 \mathrm{E}-01$ & $-2.78 \mathrm{E}+01$ & $5.83 \mathrm{E}+03$ & $1.12 \mathrm{E}-04$ \\
\hline
\end{tabular}


Dwevedi, R. et al. / J. Appl. \& Nat. Sci. 13(3), 1072 - 1082 (2021)

Table 2. Summary of the tested GAM distribution function

\begin{tabular}{|c|c|c|c|c|c|}
\hline Distribution & Mu (SE) & Sigma (SE) & $\mathrm{Nu}(\mathrm{SE})$ & Tau (SE) & GAIC \\
\hline BNB & $6.602583(0.0001367)$ & $-2.797 e+01(5.184 e-04)$ & $-2.642 e-01 \quad(6.098 e-06)$ & - & 384.8499 \\
\hline NBI & $6.593(0.178)$ & $-0.2352(0.2560)$ & - & - & 382.9027 \\
\hline NBII & $6.5918(0.1778)$ & $6.3562(0.3114)$ & - & - & 382.9028 \\
\hline NBF & $6.593(0.178)$ & $-0.2356(13.9878)$ & $0.6932(1.0609)$ & - & 384.9027 \\
\hline ZINBF & $6.593(0.205)$ & $-0.2356(0.2203)$ & $0.69318(0.01672)$ & $\begin{array}{l}-36.04 \\
20000.00\end{array}$ & 386.9027 \\
\hline ZIBNB & \multicolumn{5}{|c|}{ Algorithm did not converge } \\
\hline ZINBI & $6.5932(0.2049)$ & $-0.2352(0.2202)$ & $-36.04(20000.00)$ & - & 384.9027 \\
\hline ZANBI & $6.5928(0.1783)$ & $-0.2316(0.2592)$ & $-12.61(109.52)$ & - & 384.8866 \\
\hline
\end{tabular}

Table 3. Performance of selected GAM model

\begin{tabular}{|c|c|c|c|c|c|c|c|}
\hline Distribution & Parameters & Estimates & $\begin{array}{l}\text { Standard Errorl } \\
\text { Total Variance* }\end{array}$ & $t$ value & $p$ value & AIC & $\begin{array}{l}\text { Pseudo R } \\
\text { Square }\end{array}$ \\
\hline \multirow{3}{*}{ NB II } & (Intercept) & 92.0829055 & 18.2442744 & 5.047 & 4.70E-05 & \multirow{3}{*}{362.07} & \multirow{3}{*}{0.63} \\
\hline & Year & -0.0435887 & 0.0091491 & -4.764 & 9.34E-05 & & \\
\hline & NYWR & 0.0031346 & 0.0008044 & 3.897 & 0.000775 & & \\
\hline \multirow{3}{*}{$\mathrm{NBI}$} & (Intercept) & $1.09 \mathrm{E}+02$ & $3.59 \mathrm{E}+00$ & 30.438 & $<2 \mathrm{e}-16$ & \multirow{3}{*}{368.22} & \multirow{3}{*}{0.53} \\
\hline & Year & $-5.20 E-02$ & 1.79E-03 & -29.032 & $<2 e-16$ & & \\
\hline & NYWR & 2.13E-03 & 9.33E-04 & 2.283 & 0.0329 & & \\
\hline
\end{tabular}

poral trend as observed in MK-Kendall's test.

\section{DISCUSSION}

Water availability and breeding population of Painted Stork

Water availability has declined significantly in the KNP, and the expectedly breeding population of Painted Stork has also declined in the past 36-years. The maximum population decline was observed between 20002009, a decade of frequent droughts. However, the sharp decline in the breeding population started immediately after the severe drought of 1987, after 1987 it never matched the historical levels (Mean1980-1989= 1061, Fig. 7). Post-1998, there have been frequent droughts in the district of Bharatpur, hence limited water supply to KNP.

The volume of water released to the park explains the food abundance (fish) in the KNP (Vijayan, 1991), and hence it is expected to limit the breeding population of Painted Stork. The relationship between water availability and the breeding population is log-linear and not linear (Fig. 5B). It can be attributed to the reduction in prey density with an increase in the volume of water; hence too much volume could indicate poor habitat for breeding of Painted Stork (Chastant and Gawlik, 2018).

Also, the Painted Stork is a tactile forager, and it is dependent on physical contact for capturing the prey than visual senses; hence the volume of water can be detrimental to foraging efficiency (Urfi, 2011). Gawlik (2002) manipulated the depth of water and found that the waders are more successful in capturing the prey in shallower water than deeper, indicating the significance of water volume. Shallow water is a better habitat than deeper water for waders such as Painted Stork. An optimum volume of water is required to ensure the availability of prey, and if the volume becomes high, it decreases the effective density of the prey and hence reduces prey availability.

A significant relation of the breeding population was expected with water availability before the nesting year (MPYWR5) as observed in few studies (Reid et al., 2013, Wen et al., 2011). Though mean five-year water availability before nesting season (MPYWR5) was not 
Dwevedi, R. et al. / J. Appl. \& Nat. Sci. 13(3), 1072 - 1082 (2021)

Table 4. Performance of imputed nest count series based GAM models

\begin{tabular}{|c|c|c|c|c|c|c|}
\hline Data & Parameters & Estimates & $\begin{array}{l}\text { Standard Errorl } \\
\text { Total Variance* }\end{array}$ & $t$ value & $P$ value & $\begin{array}{l}\text { Pseudo R } \\
\text { Square }\end{array}$ \\
\hline \multirow{3}{*}{ Imputed 1} & (Intercept) & $1.15 \mathrm{E}+02$ & 1.47E+01 & 7.827 & 0.000 & \multirow{3}{*}{0.63} \\
\hline & Year & $-5.47 \mathrm{E}-02$ & 7.35E-03 & -7.443 & 0.000 & \\
\hline & NYWR & $1.56 \mathrm{E}-03$ & 4.11E-04 & 3.793 & 0.000 & \\
\hline \multirow{3}{*}{ Imputed 2} & (Intercept) & $1.26 \mathrm{E}+02$ & $1.63 \mathrm{E}+01$ & 7.759 & 0.000 & \multirow{3}{*}{0.63} \\
\hline & Year & $-6.04 \mathrm{E}-02$ & $8.13 \mathrm{E}-03$ & -7.425 & 0.000 & \\
\hline & NYWR & $1.68 \mathrm{E}-03$ & 4.35E-04 & 3.867 & 0.000 & \\
\hline \multirow{3}{*}{ Imputed 3} & (Intercept) & 93.6973967 & 19.6312925 & 4.773 & 0.000 & \multirow{3}{*}{0.43} \\
\hline & Year & -0.0439721 & 0.0098215 & -4.477 & 0.000 & \\
\hline & NYWR & 0.0015847 & 0.0005664 & 2.798 & 0.000 & \\
\hline \multirow{3}{*}{ Imputed 4} & (Intercept) & $1.37 \mathrm{E}+02$ & $1.55 \mathrm{E}+01$ & 8.825 & 0.000 & \multirow{3}{*}{0.65} \\
\hline & Year & $-6.56 \mathrm{E}-02$ & 7.75E-03 & -8.467 & 0.000 & \\
\hline & NYWR & $1.58 \mathrm{E}-03$ & 4.32E-04 & 3.662 & 0.000 & \\
\hline \multirow{3}{*}{ Imputed 5} & (Intercept) & 99.4452923 & 16.1885062 & 6.143 & 0.000 & \multirow{3}{*}{0.59} \\
\hline & Year & -0.0470955 & 0.0081015 & -5.813 & 0.000 & \\
\hline & NYWR & 0.0024047 & 0.0004881 & 4.927 & 0.000 & \\
\hline \multirow{3}{*}{$\begin{array}{l}\text { Pooled Estimates } \\
\text { of Imputed Data }\end{array}$} & Intercept & 114.2285 & 660.3739 & & 0.000 & \\
\hline & Year & -0.05435952 & 0.000165594 & & 0.000 & \\
\hline & NYWR & 0.00176288 & 3.78E-07 & & 0.000 & \\
\hline
\end{tabular}

found significant in this study, it may be affecting the habitat quality in the long term. Frederick and Ogden (2001) showed infrequent drought (poor water availability) could positively impact the breeding population of colonial birds. Infrequent droughts allow nutrition enrichment of wetlands and hence more fish/ macroinvertebrates productivity (Grutreuter et al., 1999). An observation of breeding population Painted Stork, between 1980-1989, show presence of infrequent droughts rather continuous and hence more fluctuation in nest count during this period. However, post1997, there have been frequent droughts and less water was released to the park, resulting in the continuous degradation of habitat. Authors are of the view that these frequent droughts resulted in poor habitat quality and prey availability. This limited the breeding population, even when some water was released to the park.

Regional rainfall has increased slightly ( Fig. 8); therefore, the authors expected an increase in the breeding population of Painted Stork. Nager et al. (2010) observed that the breeding population of Flamingos and Little Egret were dependent not only on the local wetlands but also on the network of wetlands at a regional scale, suggesting the importance of regional rainfall. However, in this study breeding population of Painted did not show a significant link with regional rainfall.

\section{Application of GAM and MICE model}

The negative binomial II GAMLSS model was found to be the best to model the Painted Stork breeding population expectedly. Though the tested model explained a large variability in the breeding population, exploration of other factors is essential to explain it completely. Unexplained variability in the breeding population could be because of factors that are not tested in the model, such as human disturbance, prey diversity, intra/ interspecific competition, nest substrate quality, and sex-ratio (Brooks and Dean, 2008, Urfi, 2011, Konovolav et al., 2019).

Many studies have obtained similar results with other waterbirds as well (Fewster et al., 2000, Wen et al., 2011, Reid et al., 2013). Wen et al., 2011 and Reid et al., 2013 found a negative binomial GAM model explaining the waterbird abundance and assemblage in relation to climate and hydrology of the Murray Basin in Australia. Fewster et al., 2000 applied GAM models to identify the population trend of 13 farmland species of Britain. Most studies suggest that both negative binomial I and II are suitable in describing population models (Lindén and Mäntyniemi 2011). However, in our study negative binomial, I GAMLSS model performed poorly (Fig. 3A).

This study successfully demonstrates the utility of 

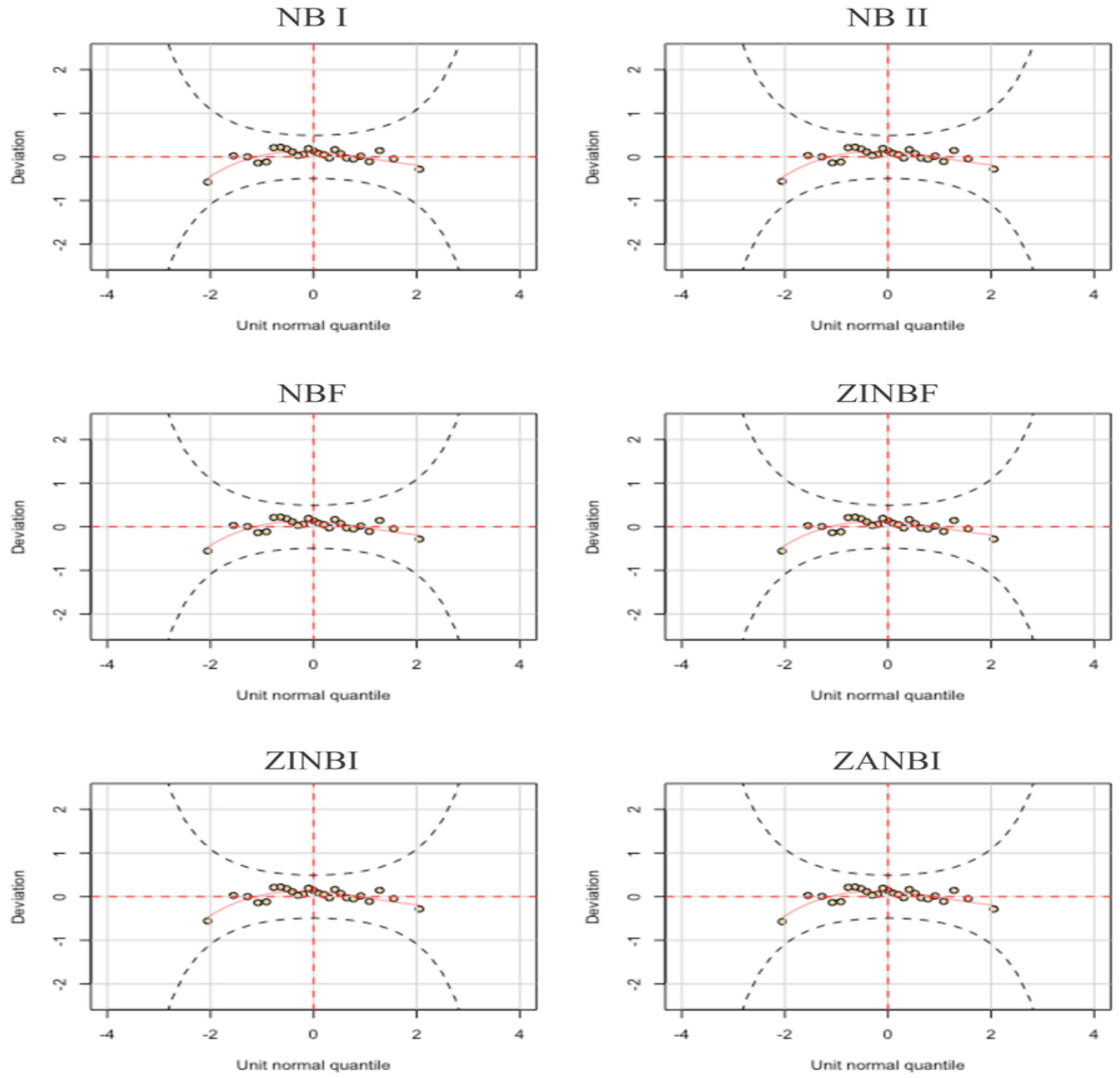

Fig. 2. Worm plot of tested GAMLSS distribution

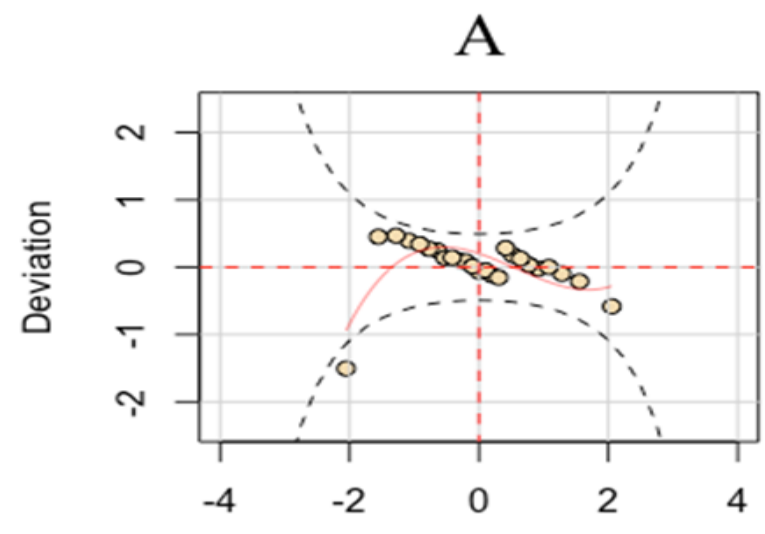

Unit normal quantile

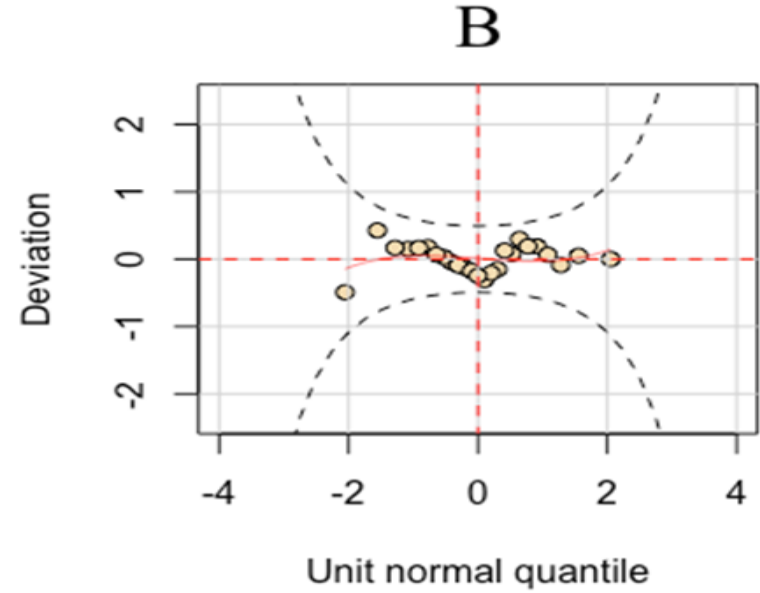

Unit normal quantile

Fig. 3. Worm plot comparison of selected A) NBI and B) NB II models 

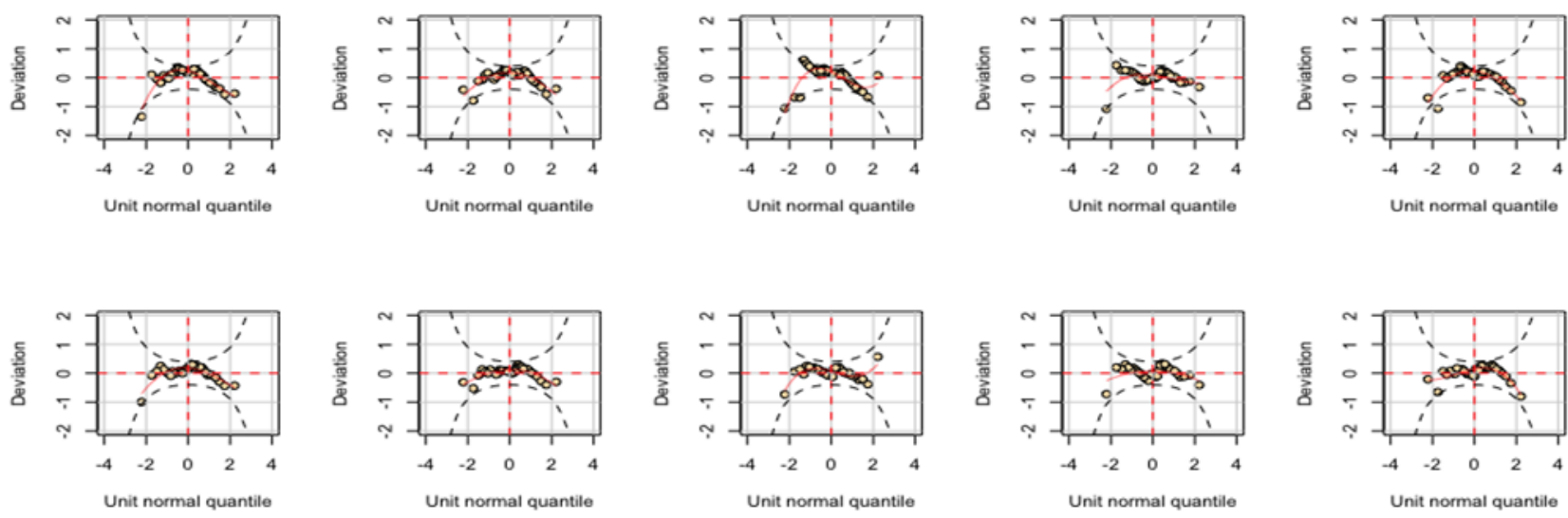

Fig. 4. Worm plot of imputation data based GAM models, First row: NBI and Second row: NBII (Imputed data sets imp1, imp2, imp 3, imp4 and imp5 are arranged from right to left)

A

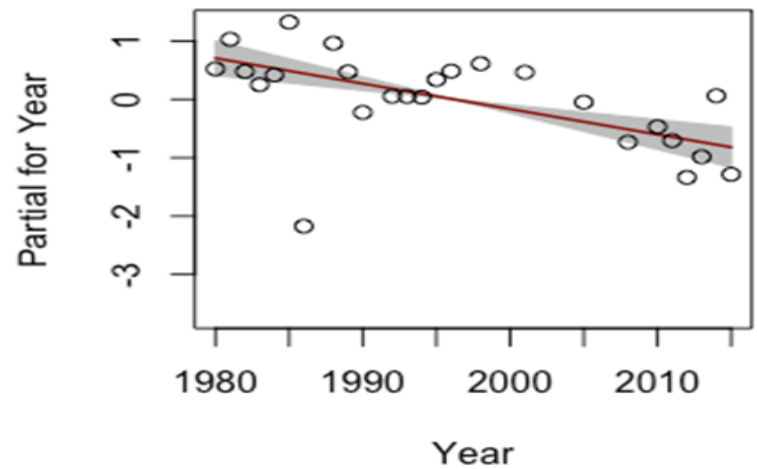

B

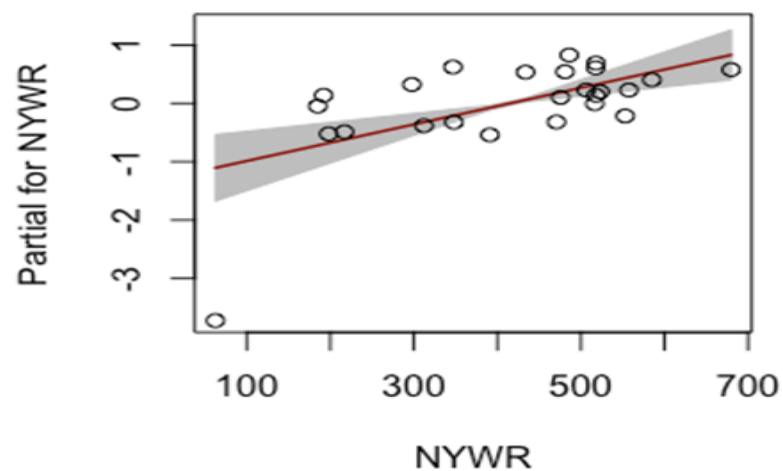

Fig. 5. Partial regression plot of A) 'Year' (Time) and B) 'NYWR' (Water released in the park during nesting) for fitted GAM model.

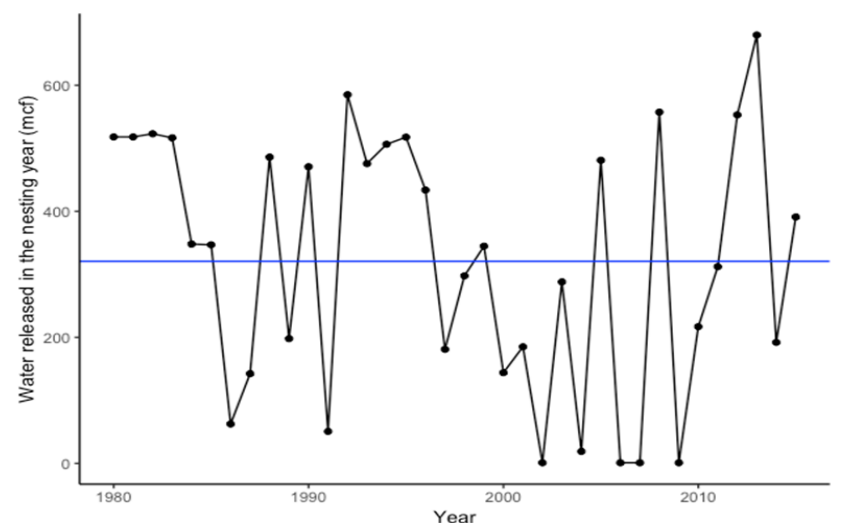

Fig. 6. Annual variation in volume of water released in the nesting season (NYWR), solid blue line show the longterm mean (320.1 mcf).

MICE imputation in modelling the breeding population. Both, imputed nest count series (no missing values) and real nest count series (with missing data) performed well and can be used for modelling. Poor performance of real data was expected because it had few missing values; however, model fit of both imputed and real data proves otherwise (compare NBI and NBII worm plots in Fig. 3 and Fig. 4). However, inconsistent nest count series is not suitable in interpreting temporal patterns, as it eliminates missing value, resulting in loss of information and a biased interpretation (Nakagawa and Freckeleton 2008, Atkinson et al., 2006). Therefore, it is best to use imputation-based models to predict the population pattern when data is missing from a data series.

This study is an important step in finding the effects of long-term phenomenon such as rainfall patterns and climate change on the breeding population. This study becomes even more significant because of limited evidence from the Indian subcontinent. It will help in acquiring more knowledge on modeling the breeding population of other waterbird species and provide valuable information for the conservation of the species and their habitat.

\section{Conclusion}

The Generalised Additive Model (GAM) and Multiple Imputation Chained Equation (MICE) model performed well in modelling long-term Painted Stork breeding pop- 


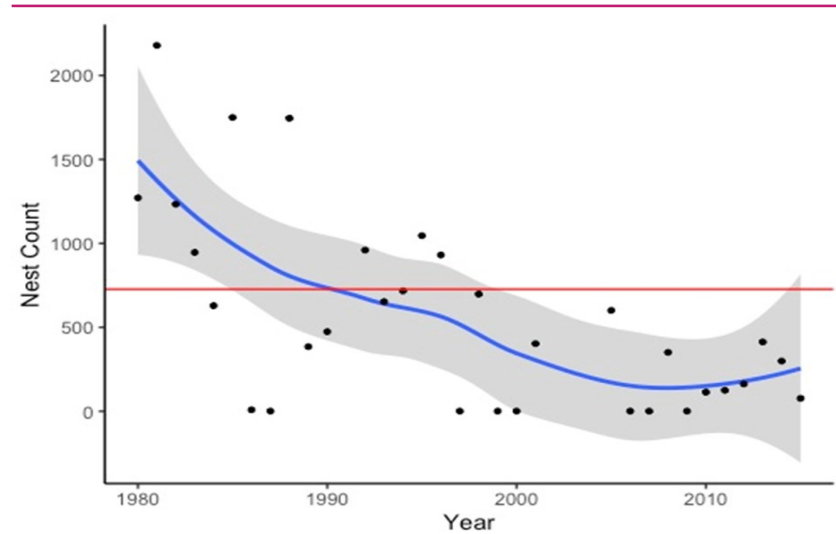

Fig. 7. Annual variation in breeding population of Painted Stork. (Blue solid line shows moving average and red line indicates long-term mean* value of nest count)* Calculation of long-term mean of nest count did not include years of breeding failure.

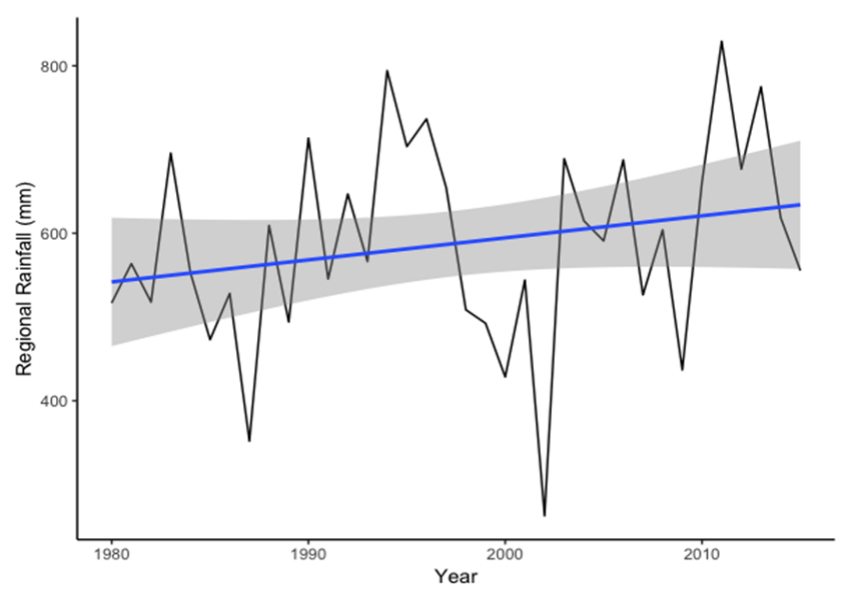

Fig. 8. Annual variation in regional rainfall $(\mathrm{mm})$

ulation. Negative binomial II was preferred over other binomial distributions to model the breeding population variation. MICE base models are suggested to be used if missing data is present in the population count. Local water availability, i.e., water released to the park each nesting season, is the most important factor explaining the variability in the breeding population. It is observed that frequent disruption in water release has led to the large population decline indicating poor habitat. Therefore, there is an urgent need to restore continuous water release in each nesting season to ensure the revival of Painted Stork breeding population to historical levels. Though water availability explains the large variability of Painted Stork breeding population, other factors, such as human activity, pollution; also needs consideration to further explain the variability in the breeding population. In the authors' view that a long-term systematic, landscape-level and institutional monitoring of breeding population is needed for better understanding and conservation initiative of Painted Stork, and in general, breeding birds at Keoladeo National Park.

\section{ACKNOWLEDGEMENTS}

Authors are thankful to the BNHS and WWF-India, allowing access to their library for the collection of the reports. Authors acknowledge the support of Director, KNP and Forest department, Government of Rajastahn for allowing access to monitoring data. $R D$ received international travel grant (TG/9788/17-HRD) from CSIR, New Delhi India to present a brief of this paper in the International Conference: Models in Population Dynamics, Ecology and Evolution, 11-19 April 2018 at University of Leicester, UK.

\section{REFERENCES}

1. Akaike, H. (1974). A new look at the statistical model identification. IEEE transactions on automatic control, 19(6), 716-723.

2. Ali, S. (1953). The Keoladeo Ghana of Bharatpur (Rajasthan). Journal of the Bombay Natural History Society, 51(3), 531-536.

3. Ali, S. \& Vijayan, V. (1983). Hydrological (ecological) Research at Keoladeo National Park, Bharatpur: First Interim Report: Bombay Natural History Society.

4. Atkinson, P. W., Austin, G. E., Rehfisch, M. M., Baker, H., Cranswick, P., Kershaw, M., ... \& Maclean, I. M. (2006). Identifying declines in waterbirds: the effects of missing data, population variability and count period on the interpretation of long-term survey data. Biological Conservation, 130(4), 549-559.

5. Baker, D. J., Clarke, R. H., \& McGeoch, M. A. (2019). The power to detect regional declines in common bird populations using continental monitoring data. Ecological Applications, 29(5), e01918. https://doi.org/10.1002/eap.1918

6. Birdlife International. (2019). Species factsheet: Mycteria leucocephala. Retrieved from http://datazone.birdlife.org/ species/factsheet/painted-stork-mycteria-leucocephala. http://datazone.birdlife.org/species/factsheet/painted-stork -mycteria-leucocephala

7. Bowler, D. E., Heldbjerg, H., Fox, A. D., de Jong, M., \& Böhning-Gaese, K. (2019). Long $\square$ term declines of European insectivorous bird populations and potential causes. Conservation Biology, 33(5), 1120-1130. https:// doi.org/10.1111/cobi.13307

8. Briggs, S., Lawler, W. \& Thornton, S. (1997). Relationships between hydrological control of river red gum wetlands and waterbird breeding. Emu, 97(1), 31-42. https:// doi.org/10.1071/MU97003

9. Brooks, W. B. \& Dean, T. (2008). Measuring the biological status of the US breeding population of Wood Storks. Waterbirds, 31(sp1), 50-62. https://doi.org/10.16 75/1524-4695(2008)31[50:MTBSOT]2.0.C O 2

10. Chastant, J. E. \& Gawlik, D. E. (2018). Water level fluctuations influence wading bird prey availability and nesting in a subtropical lake ecosystem. Waterbirds, 41(1), 35-45. https://doi.org/10.1675/063.041.0105

11. Dean, W. \& Milton, S. J. (2001). Responses of birds to rainfall and seed abundance in the southern Karoo, South Africa. Journal of Arid Environments, 47(1), 101-121. https://doi.org/10.1006/jare.2000.0693 
12. Fewster, R. M., Buckland, S. T., Siriwardena, G. M., Baillie, S. R. \& Wilson, J. D. (2000). Analysis of population trends for farmland birds using generalized additive models. Ecology, 81(7), 1970-1984. https://doi.org/10.189 0/0012-9658(2000)081[1970:AOPTFF]2.0.CO;2

13. Franklin, J. F. (1989). Importance and Justification of Long -Term Studies in Ecology. In G. E. Likens (Ed.), LongTerm Studies in Ecology: Approaches and Alternatives (pp. 3-19). New York, NY: Springer New York.

14. Frederick, P., Gawlik, D. E., Ogden, J. C., Cook, M. I. \& Lusk, M. (2009). The White lbis and Wood Stork as indicators for restoration of the everglades ecosystem. Ecological indicators, 9(6), S83-S95.https:// doi.org/10.1016/j.ecolind.2008.10.012

15. Frederick, P. C. \& Meyer, K. D. (2008). Longevity and Size of Wood Stork (Mycteria americana) Colonies in Florida as Guides for an Effective Monitoring Strategy in the Southeastern United States. Waterbirds, 31(sp1), 12-18, 17.https://doi.org/10.1675/1524-4695(2008)31\%5B12:LA SOWS\%5D2.0.CO2

16. Frederick, P. C., \& Ogden, J. C. (2001). Pulsed breeding of long-legged wading birds and the importance of infrequent severe drought conditions in the Florida Everglades. Wetlands, 21(4), 484-491. https://doi.org/10.1672/02775212(2001)021[0484:PBOLLW]2.0.CO;2

17. Freeman, S.N., Noble, D.G., Newson, S.E. \& Baillie, S.R., (2007). Modelling population changes using data from different surveys: the Common Birds Census and the Breeding Bird Survey. Bird Study, 54(1), pp.61-72. https:// doi.org/10.1080/00063650709461457

18. Gawlik, D. E. (2002). The effects of prey availability on the numerical response of wading birds. Ecological Monographs, 72(3), 329-346. https://doi.org/10.1890/0012-9615 (2002)072[0329:TEOPAO]2.0.CO;2

19. Groothuis-Oudshoorn, K. \& Van Buuren, S. (2011). Mice: multivariate imputation by chained equations in R. Journal of Statistical Software, 45(3), 1-67. http://dx.doi.org/10.18 637/jss.v045.i03

20. Gutreuter, S., Bartels, A. D., Irons, K. \& Sandheinrich, M. B. (1999). Evaluation of the flood-pulse concept based on statistical models of growth of selected fishes of the Upper Mississippi River system. Canadian Journal of Fisheries and Aquatic Sciences, 56(12), 2282-2291. https://doi.o $\mathrm{rg} / 10.1139 / \mathrm{fg} 9-161$

21. Hamed, K. H. and Rao, A. R. (1998). A modified MannKendall trend test for autocorrelated data. Journal of Hydrology, 204(1-4): 182-196. https://doi.org/10.1016/ S0022-1694(97)00125-X

22. Janzen, H. H., \& Ellert, B. H. (2017). Role of Long-Term Experiments in Understanding Ecosystem Response to Global Change. In Terrestrial Ecosystem Research Infrastructures (pp. 489-504). CRC Press.

23. Kamp, J., Frank, C., Trautmann, S., Busch, M., Dröschmeister, R., Flade, M., ... \& Sudfeldt, C. (2021). Population trends of common breeding birds in Germany 1990-2018. Journal of Ornithology, 162(1), 1-15. https:// doi.org/10.1007/s10336-020-01830-4

24. Kampichler, C., Angeler, D. G., Holmes, R. T., Leito, A., Svensson, S., van der Jeugd, H. P., \& Wesołowski, T. (2014). Temporal dynamics of bird community composition: an analysis of baseline conditions from long-term data. Oecologia, 175(4), 1301-1313. https://doi.org/10.100 7/s00442-014-2979-6

25. Karell, P., Ahola, K., Karstinen, T., Zolei, A., \& Brommer, J. E. (2009). Population dynamics in a cyclic environment: consequences of cyclic food abundance on tawny owl reproduction and survival. Journal of Animal Ecology, 78 (5), 1050-1062. https://doi.org/10.1111/j.1365-2656.200 9.01563.x

26. Knape, J. (2016). Decomposing trends in Swedish bird populations using generalized additive mixed models. Journal of Applied Ecology, 53(6), 1852-1861. https:// doi.org/10.1111/1365-2664.12720

27. Konovalov, A., Väli, Ü., Nellis, R., Nurmla, A., Sellis, U. \& Nellis, R. (2019). Solitude at periphery: lack of partners limits reproduction of the Black Stork (Ciconia nigra) at the margin of the distribution range. Ornis Fennica, 96(1).

28. Lindén, A. \& Mäntyniemi, S. (2011). Using the negative binomial distribution to model overdispersion in ecological count data. Ecology, 92(7), 1414-1421. https://doi.or $\mathrm{g} / 10.1890 / 10-1831.1$

29. Lindenmayer, D. B. \& Likens, G. E. (2009). Adaptive monitoring: a new paradigm for long-term research and monitoring. Trends In Ecology \& Evolution, 24(9), 482-486. https://doi.org/10.1016/j.tree.2009.03.005

30. Ma, Z., Li, B., Zhao, B., Jing, K., Tang, S. \& Chen, J. (2004). Are artificial wetlands good alternatives to natural wetlands for waterbirds?-A case study on Chongming Island, China. Biodiversity \& Conservation, 13(2), 333350. https://doi.org/10.1023/B:BIOC.0000006502.9613 1.59

31. Maxwell, S. L., Butt, N., Maron, M., McAlpine, C. A., Chapman, S., Ullmann, A., ... \& Watson, J. E. (2019). Conservation implications of ecological responses to extreme weather and climate events. Diversity and Distributions, 25(4), 613-625. https://doi.org/10.1111/ddi.12878

32. Miserendino, M. L., Casaux, R., Archangelsky, M., Di Prinzio, C. Y., Brand, C. \& Kutschker, A. M. (2011). Assessing land-use effects on water quality, in-stream habitat, riparian ecosystems and biodiversity in Patagonian northwest streams. Science of the Total Environment, 409 (3), 612-624. https://doi.org/10.1016/j.scitotenv.201 0.10. 034

33. Nakagawa, S. \& Freckleton, R. P. (2008). Missing inaction: the dangers of ignoring missing data. Trends in Ecology \& Evolution, 23(11), 592-596. https://doi.org/10.1016/ j.tree.2008.06.014

34. Penone, C., Davidson, A. D., Shoemaker, K. T., Di Marco, M., Rondinini, C., Brooks, T. M., . . Costa, G. C. (2014). Imputation of missing data in life-history trait datasets: which approach performs the best? Methods in Ecology and Evolution, 5(9), 961-970. https://doi.org/10.1111/2041 $-210 X .12232$

35. Ramo, C., Aguilera, E., Figuerola, J., Máñez, M. \& Green, A. J. (2013). Long-Term Population Trends of Colonial Wading Birds Breeding in Doñana (Sw Spain) in Relation to Environmental and Anthropogenic Factors. Ardeola, 60 (2), 305-326, 322. Retrieved from https://doi.org/10.13157/ arla.60.2.2013.305

36. Reinke, B. A., Miller, D. A. \& Janzen, F. J. (2019). What have long-term field studies taught us about population dynamics? Annual Review of Ecology, Evolution, and Systematics, 50, 261-278. https://doi.org/10.1146/annurev -ecolsys-110218-024717 
37. Reid, J. R., Colloff, M. J., Arthur, A. D. \& McGinness, H. M. (2013). Influence of Catchment Condition and water resource development on waterbird assemblages in the Murray-Darling Basin, Australia. Biological Conservation, 165, 25-34. https://doi.org/10.1016/j.biocon.2013.05.009

38. Russell, G. J., Bass, O. L. \& Pimm, S. L. (2002). The effect of hydrological patterns and breeding-season flooding on the numbers and distribution of wading birds in Everglades National Park. Paper presented at the Animal Conservation forum.

39. Sankhala, K. (1990). Gardens of God: The waterbird sanctuary at Bharatpur: Vikas Publishing House.

40. Sauer, J.R., Pardieck, K.L., Ziolkowski Jr, D.J., Smith, A.C., Hudson, M.A.R., Rodriguez, V., Berlanga, H., Niven, D.K. \& Link, W.A. (2017). The first 50 years of the North American breeding bird survey. The Condor: Ornithological Applications, 119(3), pp.576-593. https://doi.org/1 0.1650/CONDOR-17-83.1

41. Sergio, F., Caro, T., Brown, D., Clucas, B., Hunter, J., Ketchum, J., ... \& Hiraldo, F. (2008). Top predators as conservation tools: ecological rationale, assumptions, and efficacy. Annual Review of Ecology, Evolution, and Systematics, 39, 1-19. https://doi.org/10.1146/annurev.ecols ys.39.110707.173545

42. Shipley, J. R., Twining, C. W., Taff, C. C., Vitousek, M. N., Flack, A. \& Winkler, D. W. (2020). Birds advancing lay dates with warming springs face greater risk of chick mortality. Proceedings of the National Academy of Sciences, 117(41),25590-25594. https://doi.org/10.1073/pnas.2 009864117
43. Stasinopoulos, D. M. \& Rigby, R. A. (2007). Generalized additive models for location scale and shape (GAMLSS) in R. Journal of Statistical Software, 23(7), 1-46.

44. Taft, O. W., Colwell, M. A., Isola, C. R. \& Safran, R. J. (2002). Waterbird responses to experimental drawdown: implications for the multispecies management of wetland mosaics. Journal of Applied Ecology, 39(6), 987-1001. https://doi.org/10.1046/j.1365-2664.2002.00763.x

45. Urfi, A. J. (2011). The Painted Stork: ecology and conservation: Springer Science \& Business Media.

46. Vijayan, V. (1987). Keoladeo National Park Ecology Study. Bombay Natural History Society.

47. Vijayan, V. (1991). Keoladeo National Park Ecology Study: Final Report, 1980-1990: Bombay Natural History Society.

48. Water Resource Department Rajasthan. (2019). Yearly rainfall. Retrieved from http://water.rajasthan.gov.in/ content/water/en/waterresourcesdepartment/ WaterManagement/IWRM/annualrainfall.html

49. Weimerskirch, H. (2018). Linking demographic processes and foraging ecology in wandering albatrossConservation implications. Journal of Animal Ecology, 87 (4), 945-955. https://doi.org/10.1111/1365-2656.12817

50. Wen, L., Rogers, K., Saintilan, N. \& Ling, J. (2011). The influences of climate and hydrology on population dynamics of waterbirds in the lower Murrumbidgee River floodplains in Southeast Australia: Implications for environmental watermanagement. Ecological Modelling, 222 (1), 154-163. https://doi.org/10.1016/j.ecolmodel.201 0.0 9.016 